\title{
Editorial: Decalogue
}

Thou shalt not commit telephony. This is the first commandment.

Thou shalt not submit thy paper to two or more journals at the same time, for no editor will hold that author guiltless who submitteth his paper to two or more journals at the same time. This is the second commandment.

Thou shalt not offer a paper whose first page is numbered 73 , or 129 , or 247. Nor shalt thou in any other wise proclaim or boast or confess that thy paper is the jawbone of a dismembered doctoral thesis. This is the third commandment.

Thou shalt not cite thyself in footnotes, nay, not even though thy works be numbered as the sands of the seashore. Nor shalt thou advertise thy forthcoming articles or books, howsoever mighty. This is the fourth commandment.

Thou shalt not declare in thy covering letter how excellent is thy name in all the world, and how wondrous are thy works. This is the fifth commandment.

Thou shalt not offer to review the book that thy friend hath written, nor the book that hath been written by his wife or his son or his daughter, or his manservant or his maidservant, or his ox or his ass, even unto the third and fourth generation of them that love him. This is the sixth commandment.

Thou shalt not solve the riddle of the universe in a paper of three pages in length, with a diagram on page 2 , nay, not even though thou art a retired physician or engineer or soldier or merchant, who hast seen the world and all that therein is. This is the seventh commandment.

Thou shalt not divide thy paper into four fragments and send them to four different journals, to the end that though mayest seek to justify thy transgressions of the third and fourth commandments. This is the eighth commandment.

Thou shalt not offer to review the book that thine enemy hath written, nor the book that hath been written by his wife or his son or his 


\section{Editorial}

daughter, or his manservant or his maidservant, or his ox or his ass, even unto the third and fourth generation of them that hate thee. This is the ninth commandment.

Thou shalt not commit telephony. This is the first and last and greatest commandment. 